\title{
PREPARATION OF METAL-FIBER-REINFORCED Al-Si-Cu MATRIX COMPOSITES IN A VACUUM-SUCTION-CASTING PROCESS
}

\author{
PRIPRAVA S KOVINSKIMI VLAKNI OJAČANE Al-Si-Cu MATRICE \\ IN KOMPOZITOV, IZDELANIH S POSTOPKOM SESALNEGA \\ LITJA V VAKUUMU
}

\author{
Anna Sun, Tao He*, Yuanming Huo, Xingqian Dong, Jing Wang \\ School of Mechanical and Automotive Engineering, Shanghai University of Engineering Science, Shanghai 201620, China
}

Prejem rokopisa - received: 2019-07-23; sprejem za objavo - accepted for publication: 2019-11-04

doi:10.17222/mit.2019.170

\begin{abstract}
Lightweight alloys with high performance have become increasing popular in the world of materials engineering and science. In order to obtain high strength for an aluminum matrix alloy, the metal fiber in this work was embedded into the Al-Si-Cu matrix through a vacuum suction casting (VSC) process. Two different metal wires, i.e., copper-coated/copper-uncoated 304 stainless steel, separately, were used to prepare the Al-Si-Cu matrix composite. A microstructure investigation was conducted to study the interface reaction between the metal fiber and the matrix. The results show that the copper-coated wire was conducive to a tight connection for the metal fiber and the matrix, and it can greatly improve the comprehensive properties of the composite. The copper-coated, metal-fiber-reinforced $\mathrm{Al}-\mathrm{Si}$-Cu matrix $\left(\mathrm{CC}-\mathrm{M}_{\mathrm{f}} / \mathrm{Al}\right)$ composite was further prepared with a different fiber diameter. In order to investigate the effect of the fiber diameter on the microstructure and properties, a microstructure observation of the $\mathrm{CC}-\mathrm{M}_{\mathrm{f}} / \mathrm{Al}$ composite was conducted using scanning electron microscopy (SEM). Properties testing was carried out using a P300 electronic universal testing machine, a MHVD-1000IS microhardness tester and a FT300 resistivity tester. The experimental data indicate that the mechanical properties of the composite increase first and then decrease as the diameter of the fiber increases. When the diameter of the copper-coated fiber is $0.1 \mathrm{~mm}$, i.e., a volume fraction of $0.17 \%$, the tensile strength of the CC- $\mathrm{M}_{\mathrm{f}} / \mathrm{Al}$ composites reaches a maximum of $341.04 \mathrm{MPa}$, which is $49.33 \%$ higher than that of the original aluminum alloy. The elongation and microhardness are $54.24 \mathrm{~mm}$ and $129.1 \mathrm{HV}$, respectively. The resistivity of the $\mathrm{CC}-\mathrm{M}_{\mathrm{f}} / \mathrm{Al}$ composites is lower than that of the copper-uncoated metal fiber-reinforced $\mathrm{Al}-\mathrm{Si}-\mathrm{Cu}$ aluminum matrix $\left(\mathrm{CU}-\mathrm{M}_{\mathrm{f}} / \mathrm{Al}\right)$ composite.
\end{abstract}

Keywords: vacuum suction casting, $\mathrm{CC}-\mathrm{M}_{\mathrm{f}} / \mathrm{Al}$ and $\mathrm{CU}-\mathrm{M}_{\mathrm{f}} / \mathrm{Al}$ composite,microstructure, mechanical properties

Visoko kvalitetne lahke Al zlitine postajajo vse bolj popularne na področju inženiringa in znanosti materialov. Avtorji so zato, da bi izdelali lahek kompozitni material z visoko trdnostjo, v matrico na osnovi Al-Si-Cu vgradili kovinska vlakna. Za to so uporabili postopek vakuumskega sesalnega litja (VSC). Za izdelavo kompozita z Al-Si-Cu matrico (CC-Mf/Al) so izbrali dve različni vrsti kovinskih vlaken in sicer: z bakrom prevlečeno in neprevlečeno jekleno žico iz nerjavnega jekla tipa 304. Izvedli so mikrostrukturne preiskave in študirali reakcije na meji med kovinskimi vlakni in matrico. Rezultati so pokazali, da je matrica, ki vsebuje z bakrom prevlečena vlakna, v celoti prevodna, kar je močno izboljšalo lastnosti kompozita. Nadalje so izdelovali še CC-Mf/Al kompozite, ojačane z jeklenimi vlakni različne debeline. Vpliv debeline vlaken na mikrostrukturo in lastnosti CC-Mf/Al so analizirali z vrstičnim elektronskim mikroskopom (SEM). Mehanske lastnosti kompozitov so določili s pomočjo elektronskega univerzalnega trgalnega stroja P300. Trdoto kompozitov so določili na merilniku mikrotrdote MHVD-1000IS in prevodnost na merilniku upornosti FT300. Eksperimentalni rezultati kažejo, da se mehanske lastnosti kompozita izboljšujejo najprej, ko premer vlaken raste $($ do $0,1 \mathrm{~mm})$, in nato začnejo padati, ko premer raste od $0,1 \mathrm{~mm}$ do $0,25 \mathrm{~mm}$. Pri premeru $z$ bakrom prevlečenih vlaken $0,1 \mathrm{~mm}$ je njihov volumski delež $0,17 \%$ in CC-Mf/Al kompozit ima takrat maksimalno trdnost $341,04 \mathrm{MPa}$, kar je za 49,33 \% višja trdnost kot jo ima originalna Al zlitina. Raztezek in mikrotrdota sta 54,24 mm in $129,1 \mathrm{HV}$. Upornost CC-Mf/Al kompozitov, ki vsebujejo z bakrom oplaščena vlakna, je nižja od tistih, ki vsebujejo neoplaščena jeklena vlakna.

Ključne besede: vakuumsko sesalno litje, $\mathrm{CC}-\mathrm{M}_{\mathrm{f}} / \mathrm{Al}$ in $\mathrm{CU}-\mathrm{M}_{\mathrm{f}} / \mathrm{Al}$ kompoziti, mikrostruktura, mehanske lastnosti

\section{INTRODUCTION}

The Al-Si-Cu alloy is widely used due to its excellent castability, high specific strength, ductility, and corrosion resistance as well as a low density and a small coefficient of linear expansion. However, it is still difficult to meet the requirements of modern mechanical structural parts for conventional $\mathrm{Al}-\mathrm{Si}-\mathrm{Cu}$ alloys. It is necessary to further improve the performance of the $\mathrm{Al}-\mathrm{Si}-\mathrm{Cu}$ alloy. ${ }^{1-4}$

*Corresponding author's e-mail:

hetao@sues.edu.cn (He Tao)
A metal fiber was proved to further improve the performance of conventional $\mathrm{Al}-\mathrm{Si}-\mathrm{Cu}$ alloys. A composite material is called fiber-reinforced aluminum matrix composite, prepared by inserting the metal fiber as a reinforcing phase into the matrix phase of an aluminum alloy. ${ }^{5-7}$ The prepared composites hold the specific properties of light weight and high strength, which is suitable for manufacturing the special parts in the automotive, aerospace, rail transit, et al. ${ }^{8,9}$

At present, the preparation of metal-fiber-reinforced composite materials attracts the attention of many researchers. W. Tao et al. ${ }^{10}$ proposed that the continuous 
long fibers, such as carbon (graphite) fiber, SiC fiber, $\mathrm{Al}_{2} \mathrm{O}_{3}$ fiber, and stainless steel wire, have been applied to aluminum matrix composites, resulting in an improvement of its tensile strength. L. Youfeng et al. ${ }^{11}$ believed that the transverse elastoplastic properties and shear elastoplastic properties with the increase of fiber volume content. M. Xiaobin et al. ${ }^{12}$ found that the tensile strength and elastic modulus of continuous carbonfiber-reinforced aluminum-matrix composites were significantly higher than that of the general metal matrix. B. L. Dasari et $a .^{5}$ found that the strength, hardness, and ductility were greatly improved for the prepared graphene-reinforced aluminum matrix composites with different volume fractions. When preparing the TiNi/Al composites, Y.g Shengnan et al. ${ }^{13}$ found that the quasi-static tensile mechanical properties increased with the increase of the volume fraction of TiNi fibers.

The VSC technique was used to prepare the metal-fiber-reinforced Al-Si-Cu composites in this work. The VSC process is a casting process based on the self-gravity and the pressure difference between the melting chamber and the suction casting chamber to complete the filling operation of the alloy liquid and solidify under the low-pressure and vacuum state. ${ }^{14}$ By using the VSC process, the molten fluid of the Al-Si-Cu alloy was prone to enter the cavity of the copper mold for preparing the metal-fiber-reinforced Al-Si-Cu composites, such that the interface between the fiber and the matrix has relatively few micro-holes. It provides a basic guarantee to improve the performance of the composite material.

Some researchers published many scientific articles on VSC. Z. Szklarz et al. ${ }^{15}$ improved the microstructure of the casting, i.e., refining the grains, and increasing the hardness and strength of the material, by the VSC process. L.F. Qi et al. ${ }^{16}$ prepared carbon-fiber composites using vacuum infiltration extrusion (LSEVI). The results showed that the $2 \mathrm{D}-\mathrm{C}_{\mathrm{f}} / \mathrm{Al}$ composites have a tensile strength of $112.5 \%$ higher than that of the matrix. Reference $^{17}$ shows the method of copper coating on the surface of the fiber can contribute to controlling the wettability and interfacial reaction between the fiber and the liquid metal. B. B. Singh ${ }^{18}$ investigated the strength improvement of the aluminum matrix alloy using $\mathrm{Cu}$-coated carbon fiber and the addition of $\mathrm{Mg}$. It was found that the wettability of the carbon fiber and the matrix was improved without using an interfacial reaction investigated the strength improvement of the aluminum matrix alloy. This indicates that copper coated on the surface of the fiber can improve the performance of the composite. However, most researches focused on the effect of short nonmetallic fibers on the reinforced quality of the Al-Si-Cu matrix composite. It is difficult to find the application of long metal fibers, especially 304 stainless steel, in the preparation of the fiber-reinforced $\mathrm{Al}-\mathrm{Si}-\mathrm{Cu}$ matrix composites.
This work aims to prepare fiber-reinforced $\mathrm{Al}-\mathrm{Si}-\mathrm{Cu}$ matrix composites using long metal fibers of 304 stainless steel. Firstly, the $\mathrm{CC}-\mathrm{M}_{\mathrm{f}} / \mathrm{Al}$ and $\mathrm{CU}-\mathrm{M}_{\mathrm{f}} / \mathrm{Al}$ composites were prepared by the VSC method, whose microstructure and mechanical properties were compared and analyzed. Secondly, CC-M $\mathrm{M}_{\mathrm{f}} / \mathrm{Al} / \mathrm{CU}-\mathrm{M}_{\mathrm{f}} / \mathrm{Al}$ composites were prepared using different diameters of 304 metal fiber. And then, the effect of the diameter of the metal fiber on the comprehensive mechanical properties and electrical resistivity of the $\mathrm{CC}-\mathrm{M}_{\mathrm{f}} / \mathrm{Al}$ $/ \mathrm{CU}-\mathrm{M}_{\mathrm{f}} / \mathrm{Al}$ composites were discussed. Finally, some conclusions can be drawn.

\section{EXPERIMENTAL PART}

\subsection{Materials preparations}

The high-purity particles of $99.99 \% \mathrm{Al}, 99.95 \% \mathrm{Si}$, and $99.99 \% \mathrm{Cu}$ were used as the raw materials in this experiment. The chemical composition mass fraction is shown in Table 1. The 304 stainless-steel wire was selected as the metal fiber, and the length of the metal fiber is $90 \mathrm{~mm}$. Figure $\mathbf{1}$ shows a micrograph of the copper-uncoated fiber and copper-coated fiber of 304 stainless steel, and the thickness of the copper-coated fiber is about $2 \mu \mathrm{m}$. Figure 2 shows a schematic diagram of the VSC in this experiment.
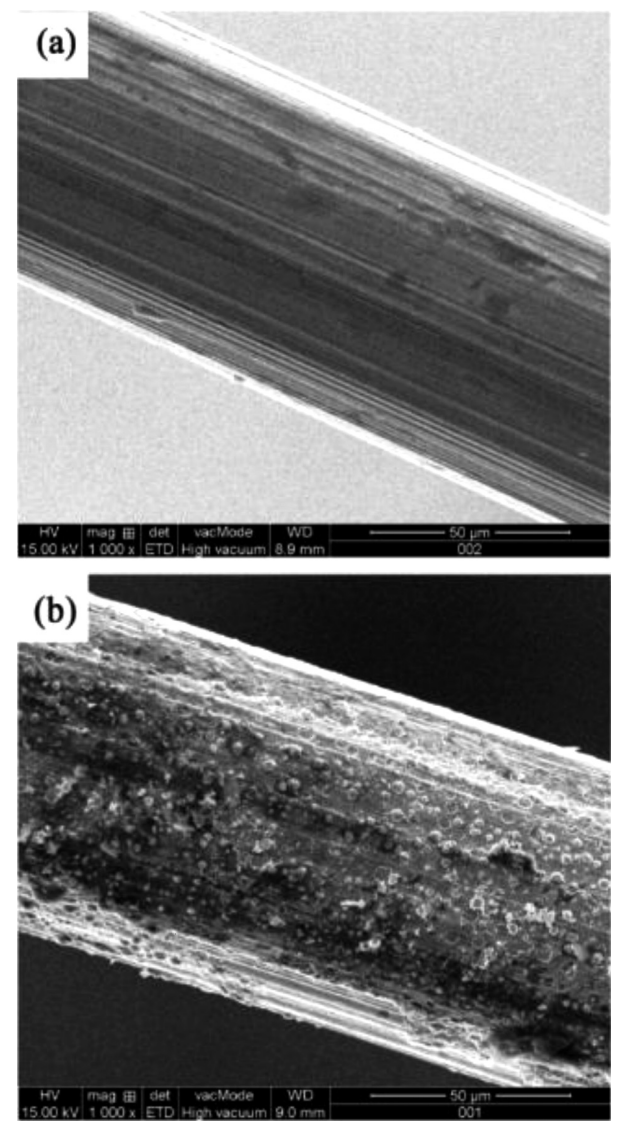

Figure 1: Fiber surface topography of: a) copper-uncoated fiber, b) copper-coated fiber 


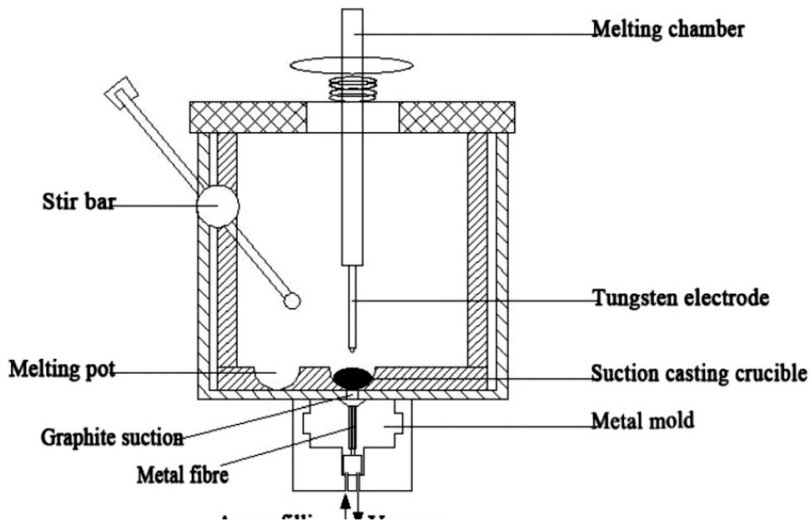

Figure 2: Schematic diagram of vacuum-suction casting

The experimental procedure consists of three steps. First, the metal fibers were fixed in the copper mold. The raw materials were cleaned using an ultrasonic oscillator. The decontaminated raw materials were placed in a desiccator for drying. Second, the raw materials were smelted and uniformly stirred in a high-vacuum arcmelting chamber. Finally, the alloy liquid entered the copper mold under the effect of internal pressure difference and self-gravity. The prepared samples of $\mathrm{CC}-\mathrm{M}_{\mathrm{f}} / \mathrm{Al}$ or $\mathrm{CU}-\mathrm{M}_{\mathrm{f}} / \mathrm{Al}$ composites are shown in Figure 3.

Table 1: Al-Si-Cu alloy chemical composition (mass fraction, w/\%)

\begin{tabular}{|c|c|c|c|c|}
\hline Element & $\mathrm{Al}$ & $\mathrm{Si}$ & $\mathrm{Cu}$ & $\mathrm{Mg}$ \\
\hline$w / \%$ & Balance & $4.5-5.5$ & $1.0-1.5$ & $0.4-0.55$ \\
\hline
\end{tabular}

A series of samples of $\mathrm{CC}-\mathrm{M}_{\mathrm{f}} / \mathrm{Al}$ and $\mathrm{CU}-\mathrm{M}_{\mathrm{f}} / \mathrm{Al}$ composites were prepared using VSC by changing the diameter of the metal fibers. The detailed diameter was selected as $0.06 \mathrm{~mm}, 0.08 \mathrm{~mm}, 0.1 \mathrm{~mm}, 0.15 \mathrm{~mm}, 0.2$ $\mathrm{mm}$, and $0.25 \mathrm{~mm}$. The influence of the different process parameters on the microstructure, mechanical properties and electrical conductivity of the Al-Si-Cu matrix composites were investigated as below.

\subsection{Composites treatment after preparation}

The prepared composite samples were heat treated using a SX2-5-12N box-type resistance furnace in two stages: Stage 1: solution treatment at $525{ }^{\circ} \mathrm{C} \times 8 \mathrm{~h}+$ $60{ }^{\circ} \mathrm{C}$ water quenching; Stage 2 : aging treatment $160{ }^{\circ} \mathrm{C}$

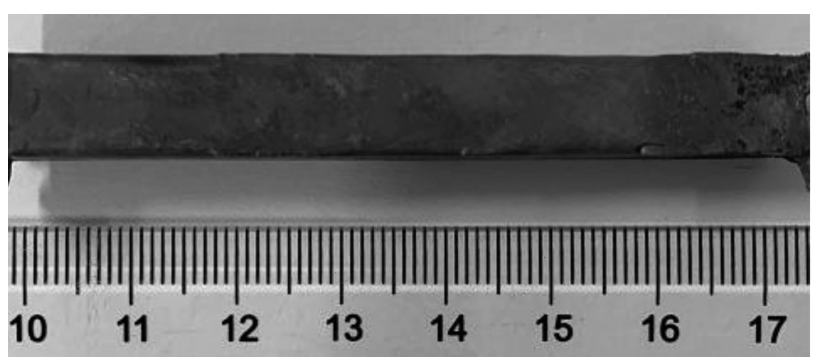

Figure 3: The prepared samples of $\mathrm{CC}-\mathrm{M}_{\mathrm{f}} / \mathrm{Al}$ and $\mathrm{CU}-\mathrm{M}_{\mathrm{f}} / \mathrm{Al}$ composites

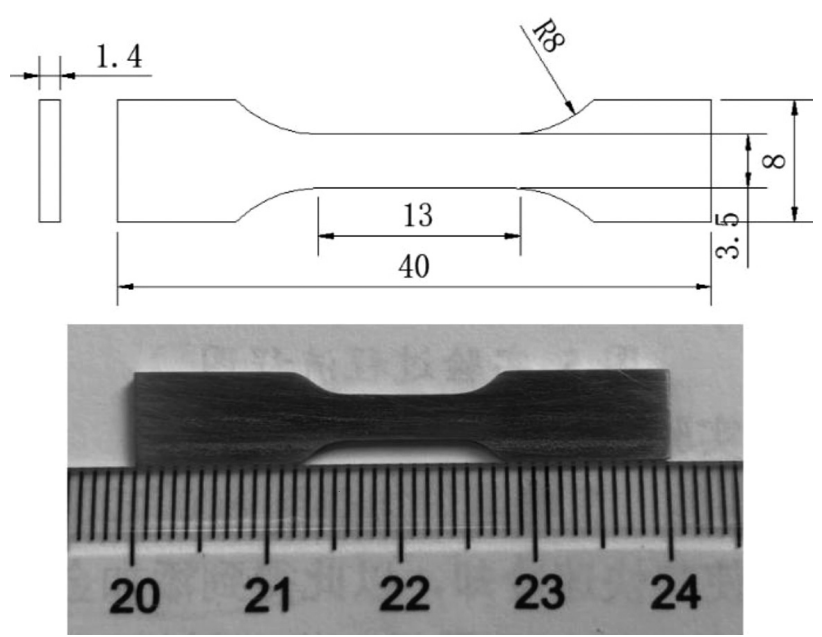

Figure 4: Standard tensile-test pieces

$\times 4 \mathrm{~h}+$ air cooling. After the heat treatment, the samples were machined into standard tensile-test pieces (Figure 4) using the DK7632 type slow wire cutting machine. The tensile tests were conducted following the ASTM: E8M standard. All the specimens were gradually ground using waterproof abrasive paper from coarse to fine, and then polished on the MP-2B double-disc stepless grinding and polishing machine. The etching of specimens was carried out at room temperature using an acid solution of $5 \mathrm{~mL} \mathrm{HNO}_{3}+2 \mathrm{~mL} \mathrm{HF}+3 \mathrm{~mL} \mathrm{HCl}+$ $190 \mathrm{~mL} \mathrm{H}_{2} \mathrm{O}$.

\subsection{Properties test and microstructure observation}

The tensile tests were carried out at a speed of 2 $\mathrm{mm} / \mathrm{min}$ on a P300 electronic universal testing machine. The hardness tests were carried out on a $(9 \times 9 \times 15) \mathrm{mm}$ test piece in an MHVD-1000IS-type hardness tester. Each test piece was measured five times in a symmetrical position, and the average value was recorded. The resistivity test of the specimens using a four-terminal measurement method on an FT300 type resistivity tester. The average value was obtained from three measurements. The microstructures of the composites samples were observed using a SU8070 scanning electron microscope (SEM).

\section{RESULTS AND DISCUSSION}

\subsection{Effect of copper coating on the interface micro- structure of the metal fiber}

Figure 5 shows the microstructure and EDS analysis of the copper-uncoated fiber composites material and the copper-coated fiber composites material. Figure 5a shows a 1000-times microstructure of a $\mathrm{CU}-\mathrm{M}_{\mathrm{f}} / \mathrm{Al}$ composite. It can be seen that there are many microporosities between the interface of the metal fiber and matrix. And, eutectic silicon exists around the fiber, the grain size is between $2.3 \mu \mathrm{m}$ and $3.2 \mu \mathrm{m}$. The eutectic silicon was 
A. SUN et al.: PREPARATION OF METAL-FIBER-REINFORCED Al-Si-Cu MATRIX COMPOSITES ...
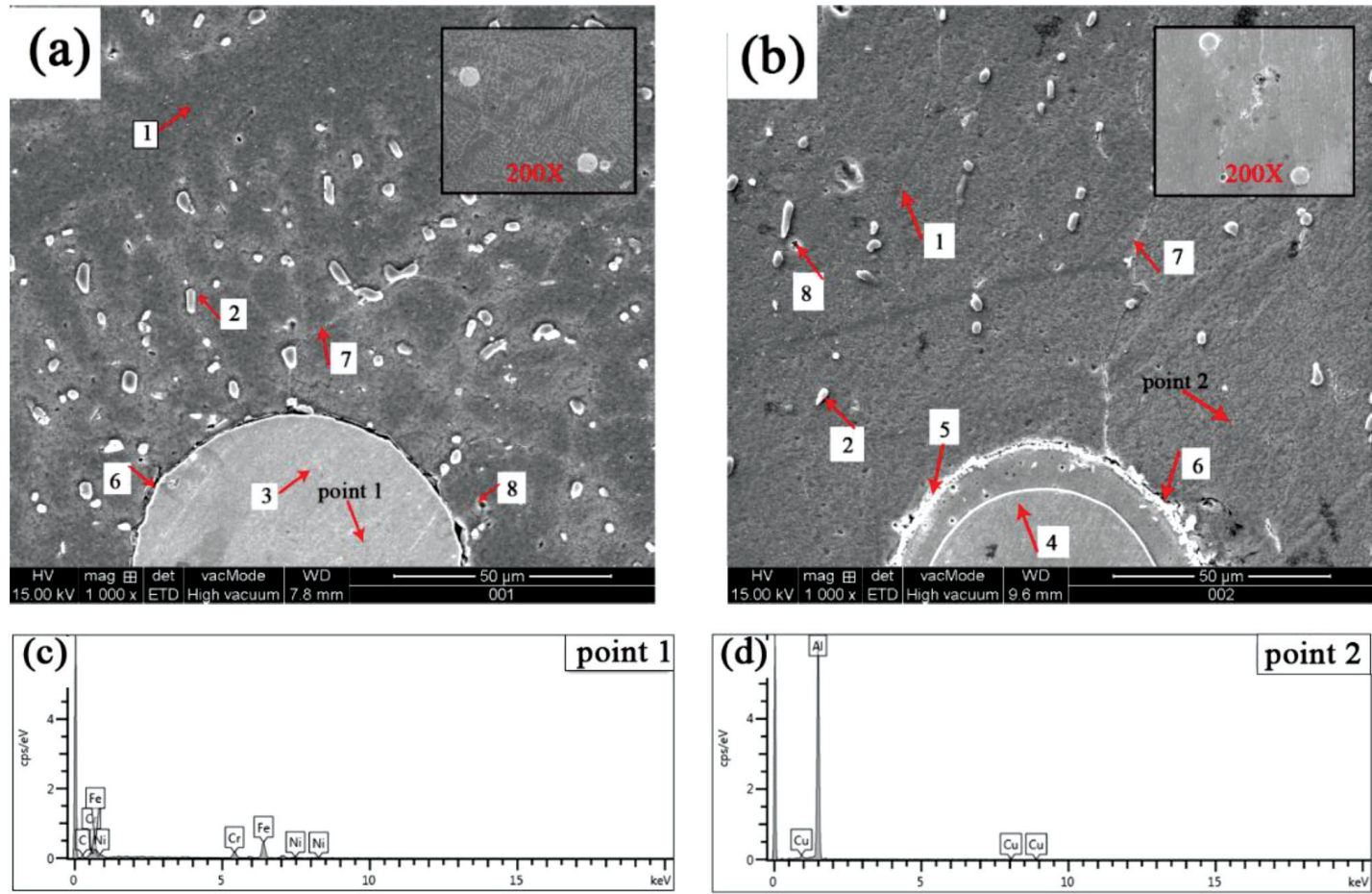

Figure 5: a) microstructure of copper-uncoated fiber composites, b) microstructure of copper-coated fiber composites, c) EDS analysis of copper-uncoated fiber 304 stainless steel, d) EDS analysis of Al-Si-Cu matrix (1- $\alpha$ solid solution $+\mathrm{Al}_{2} \mathrm{Cu}$ strengthening phase; 2-eutectic silicon; 3-copper-uncoated fiber; 4-copper-coated fiber; 5-copper sheet; 6-microporosity; 7-grain boundaries; 8-shrinkage cavity and porosity)
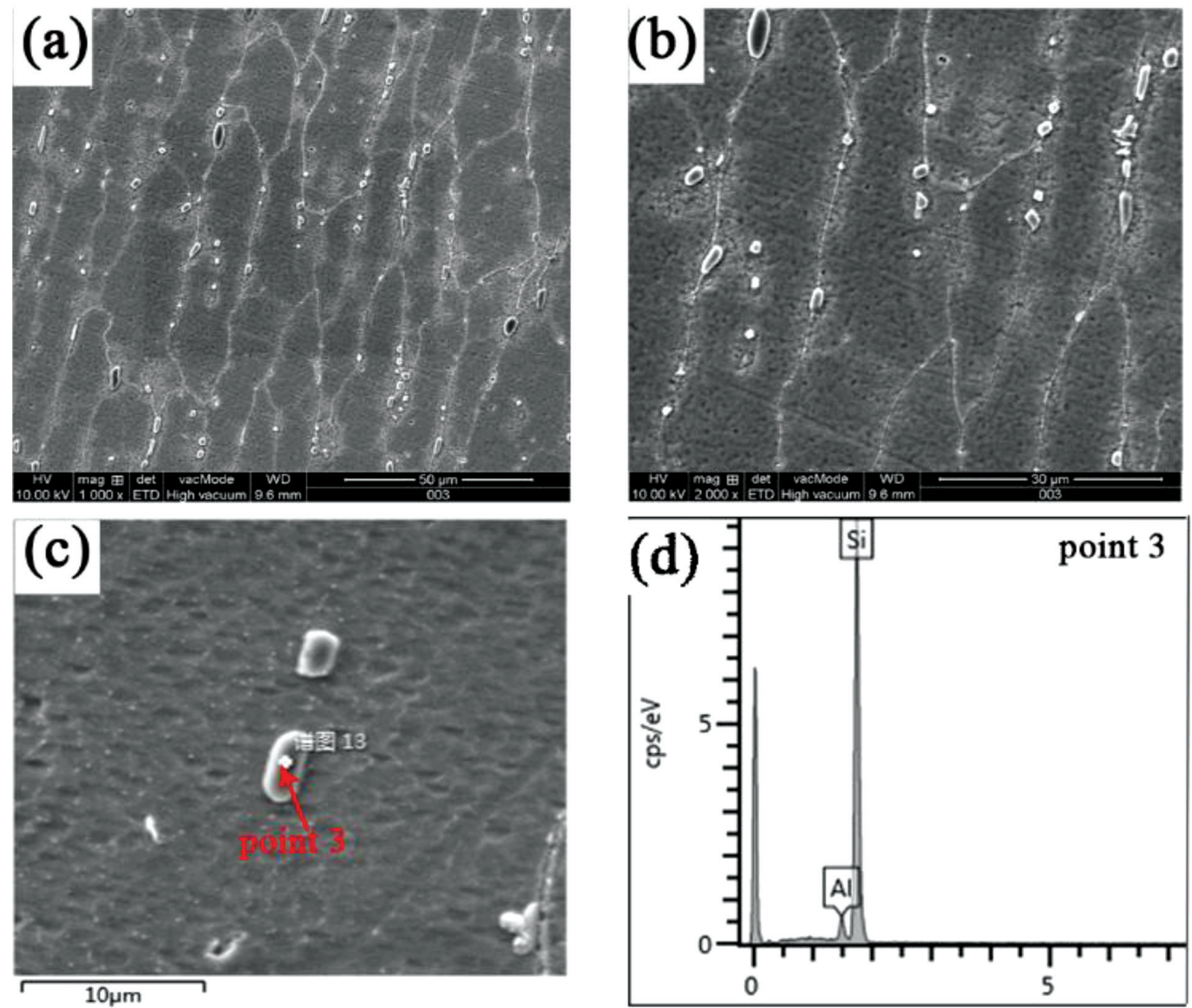

Figure 6: a) microstructure of fiber-reinforced $\mathrm{Al}-\mathrm{Si}-\mathrm{Cu}$ matrix composites, 1000 times, b) microstructure of fiber-reinforced $\mathrm{Al}-\mathrm{Si}-\mathrm{Cu}$ matrix composites, 2000 times, c) eutectic silicon microstructure, d) EDS diagram 
mainly found along the grain boundary. And, the density of eutectic silicon is relatively higher around the metal fibers than the other areas. These particles of eutectic silicon can leads to stress concentrations near the fiber during the tension test. Figure 5 c) shows the copperuncoated fiber EDS analysis in Figure 5a. It is clear that the $\mathrm{Fe}$ content in the fiber is much higher than the other elements. Figure $\mathbf{5 b}$ shows the microstructure of a $\mathrm{CC}-\mathrm{M}_{\mathrm{f}} / \mathrm{Al}$ composite. The surface of the copper-coated fiber is in the molten state during the preparation process, so that the fiber and the matrix are well combined. The copper surface of the fiber surface compensates for the gap between the metal fiber and the matrix, the eutectic silicon is uniformly dispersed in the $\alpha$ solid solution, the grain size is between $2.7 \mu \mathrm{m}$ and $5.3 \mu \mathrm{m}$, and there is some discontinuous microporosity at the interface between the fiber and the matrix. Figure 5d shows the Al-Si-Cu matrix EDS analysis in Figure 5b. It is clear that the matrix is mostly $\mathrm{Al}$ and $\mathrm{Cu}$.

Figure 6 shows the microstructure of the fiber-reinforced $\mathrm{Al}-\mathrm{Si}-\mathrm{Cu}$ matrix composites. Figure 6a shows 1000-times magnification of the microstructure of the fiber-reinforced $\mathrm{Al}-\mathrm{Si}-\mathrm{Cu}$ matrix composites. It can be seen from Figure 6a that tiny columnar crystals were formed in the solidification of the castings, and it distributes in rows. The eutectic silicon is mostly located in the grain boundary, and the average width of the eutectic silicon is $2.3-5.7 \mu \mathrm{m}$. Since the number of grain boundaries is large and the area of each grain boundary is small, it helps to improve the mechanical properties of the prepared composite. ${ }^{19}$ Figure $6 \mathbf{b}$ shows the 2000-times local magnifying microstructure of the $\mathrm{Al}-\mathrm{Si}-\mathrm{Cu}$ matrix composites. The eutectic silicon is irregular or short rod-shaped, and is composed of $\alpha-\mathrm{Si}$ solid crystals and distributed in the grain boundary. At the same time, the $\theta\left(\mathrm{Al}_{2} \mathrm{Cu}\right)$ equivalent strengthening phase is solid-dissolved in the $\alpha$ matrix, so no strengthening phase is observed in the microstructure of the composites. It can be seen in figure $\mathbf{6 c}$ and figure $\mathbf{6 d}$ a magnified view of the microstructure of the local eutectic silicon and EDS spectrum analysis. The short rod-like eutectic silicon is distributed in the $\alpha$ solid solution, which is a good strengthening of the matrix.

\subsection{Effect of different metal fiber diameters on the mechanical properties of the composites}

Figure 7 shows the effect of different metal fiber diameters of copper-coated and copper-uncoated fibers on the tensile strength, elongation and microhardness of the Al-Si-Cu matrix composites. The addition of fibers in the composites will result in a reinforcing phase/matrix interface, so the interfacial bonding strength will directly affect the properties of the composites. ${ }^{20}$ It can be seen from Figure $\mathbf{7 a}$ the effect of different metal fiber diameters on the tensile strength of $\mathrm{Al}-\mathrm{Si}-\mathrm{Cu}$ matrix composites. When the diameter of the metal fiber is between $0.05 \mathrm{~mm}$ and $0.15 \mathrm{~mm}$, that is, the volume fraction of the metal fiber is $0.06 \%$ to $0.17 \%$, the tensile strength of the Al-Si-Cu matrix composites increases first and then decreases with an increase of the diameter of the metal fiber. When the diameter is between 0.15 $\mathrm{mm}$ and $0.25 \mathrm{~mm}$, i.e., the volume fraction of the metal fiber is $0.17 \%$ to $1.2 \%$, it also increases first and then decreases gradually with the increase of the diameter of the metal fiber. When the diameter of the copper-coated fiber is $0.1 \mathrm{~mm}$, and the volume fraction of the metal fiber is $0.17 \%$, the tensile strength of $\mathrm{CC}-\mathrm{M}_{\mathrm{f}} / \mathrm{Al}$ composites is $341.04 \mathrm{MPa}$, which is higher than the tensile strength of $228.38 \mathrm{MPa}$ for the pure matrix $\mathrm{Al}-\mathrm{Si}-\mathrm{Cu}$ alloy of about $49.33 \%$. Moreover, the tensile strength of the $\mathrm{CC}-\mathrm{M}_{\mathrm{f}} / \mathrm{Al}$ composites is higher than that of the CU-M $\mathrm{M}_{\mathrm{f}} / \mathrm{Al}$ composites about $9.04-32.92 \%$.
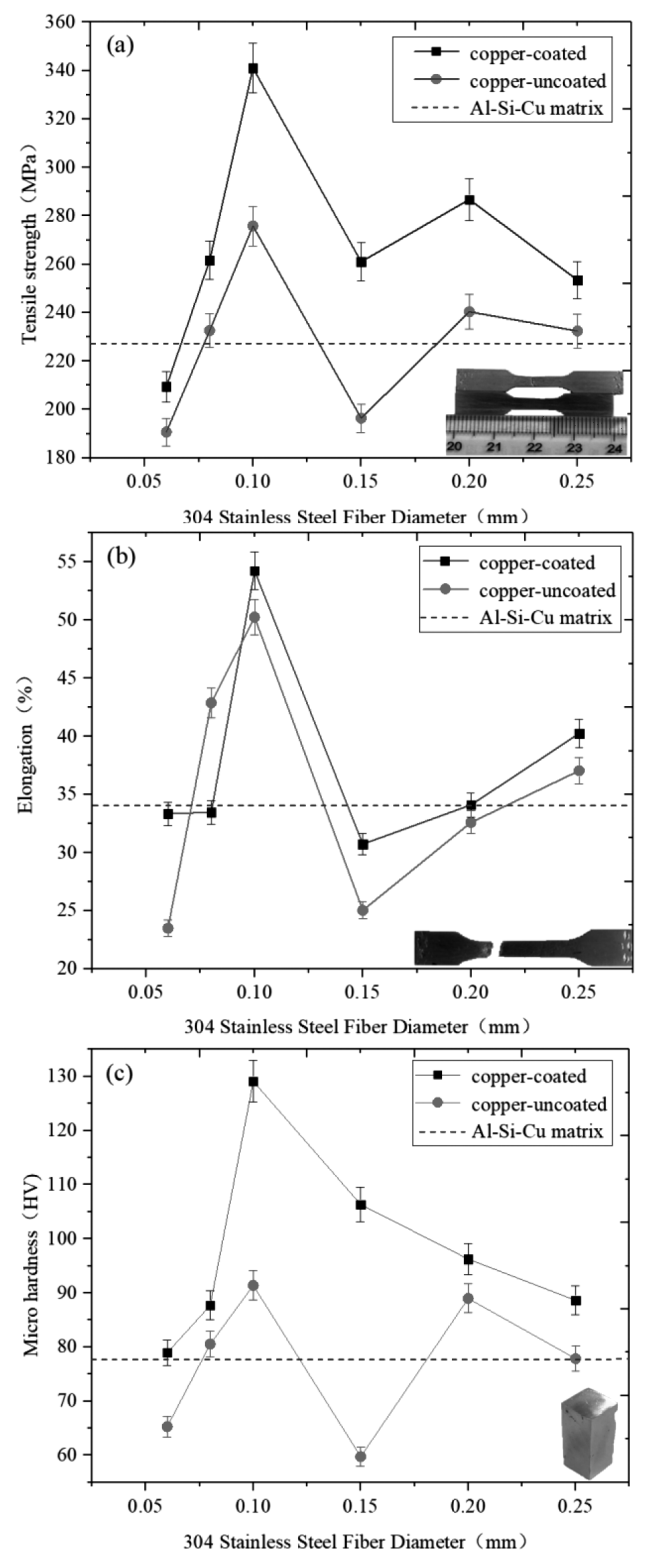

Figure 7: Effect of different metal-fiber diameters of the composites on: a) tensile strength, b) elongation, c) hardness value 
It can be seen from Figure $\mathbf{7 b}$ that the effect of different metal-fiber diameters on the elongation of $\mathrm{Al}-\mathrm{Si}-\mathrm{Cu}$ matrix composites. When the diameter of the metal fiber is between $0.05 \mathrm{~mm}$ and $0.15 \mathrm{~mm}$, the elongation of the $\mathrm{Al}-\mathrm{Si}-\mathrm{Cu}$ matrix composite increases first and then decreases with the increase of the metal-fiber diameter. When the diameter is between $0.15 \mathrm{~mm}$ and $0.25 \mathrm{~mm}$, the elongation always increases. When the diameter of the copper-coated fiber is $0.1 \mathrm{~mm}$, i.e., the volume fraction of the metal fiber is $0.17 \%$, the elongation is $54.24 \mathrm{~mm}$, which is higher than that of the pure matrix Al-Si-Cu alloy of about $43.3 \%$. Moreover, the elongation of the surface of the $\mathrm{CC}-\mathrm{M}_{\mathrm{f}} / \mathrm{Al}$ composites material is generally higher than that of the $\mathrm{CU}-\mathrm{M}_{\mathrm{f}} / \mathrm{Al}$ composites material.

It can be seen from Figure 7c the effect of different metal fiber diameters on the microhardness of $\mathrm{Al}-\mathrm{Si}-\mathrm{Cu}$ matrix composites. As the diameter of the copper-coated metal fiber increases, the microhardness of $\mathrm{CC}-\mathrm{M}_{\mathrm{f}} / \mathrm{Al}$ composites increases first and then decreases. The microhardness of the copper-coated fiber is up to 129.1 $\mathrm{HV}$, and the microhardness of the $\mathrm{Al}-\mathrm{Si}-\mathrm{Cu}$ alloy matrix is $77.51 \mathrm{HV}$, so the microhardness is improved by about $66.56 \%$ compared with the Al-Si-Cu alloy matrix. As the diameter of the copper-uncoated metal fiber increases, the microhardness of the CU-M $\mathrm{M}_{\mathrm{f}} / \mathrm{Al}$ composites appeared with two peak states, i.e., $91.37 \mathrm{HV}$ and 88.96 $\mathrm{HV}$. The microhardness of the $\mathrm{CC}-\mathrm{M}_{\mathrm{f}} / \mathrm{Al}$ composites is higher than that of the $\mathrm{CU}-\mathrm{M}_{\mathrm{f}} / \mathrm{Al}$ composites by about $8.18-78 \%$.

The reason for the above phenomenon was that when the fiber diameter is less than $0.1 \mathrm{~mm}$, copper coated on the surface of the fiber can eliminate the microporosity between the fiber and the matrix. However, when the fiber diameter is larger than $0.1 \mathrm{~mm}$, as the fiber diameter increases, the gap between the fiber and the matrix becomes increasingly larger, and the copper-coated on

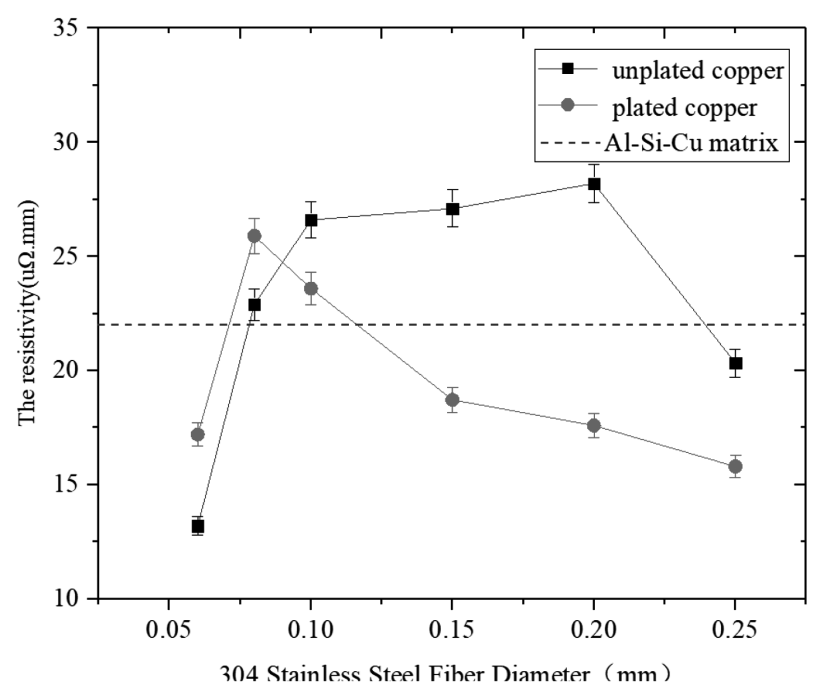

Figure 8: Effect of different metal-fiber diameters on the electrical conductivity of composites the surface of the fiber is not enough to fill the gap between the fiber and the matrix, so the mechanical properties first increase and then decrease.

\subsection{Effect of different metal Fiber diameters on the re- sistivity of the composites}

Figure 8 shows the effect of different metal fiber diameters on the resistivity of CC- $\mathrm{M}_{\mathrm{f}} / \mathrm{Al}$ and $\mathrm{CU}-\mathrm{M}_{\mathrm{f}} / \mathrm{Al}$ composites. As we can see from Figure 8, the resistivity of the $\mathrm{Al}-\mathrm{Si}-\mathrm{Cu}$ matrix composites increases first and then decreases with an increase of the diameter of the metal fiber. When the fiber diameter is less than 0.09 $\mathrm{mm}$, the resistivity of the $\mathrm{CC}-\mathrm{M}_{\mathrm{f}} / \mathrm{Al}$ composites material is higher than that of the $\mathrm{CU}-\mathrm{M}_{\mathrm{f}} / \mathrm{Al}$ composites material. When the diameter of the metal fiber is greater than 0.09 $\mathrm{mm}$, the resistivity of the $\mathrm{CU}-\mathrm{M}_{\mathrm{f}} / \mathrm{Al}$ composites material is higher than that of the $\mathrm{CC}-\mathrm{M}_{\mathrm{f}} / \mathrm{Al}$ composites material. With the fiber diameter increases, the metal fiber on the relative distribution area in the matrix increases, the bonding interface between the metal fiber and matrix increases. Therefore, the gap between the metal fiber and the matrix is continuously increased, eventually resulting in a large electrical resistivity. When the diameter of the copper-uncoated fiber is $0.2 \mathrm{~mm}$, the maximum resistivity is $28.2 \mu \Omega \cdot \mathrm{mm}$. When the diameter of the copper-coated fiber is $0.09 \mathrm{~mm}$, the maximum resistivity is $25.9 \mu \Omega \cdot \mathrm{mm}$.

The reason for the above phenomenon is that the resistivity of the matrix element $\mathrm{Fe}$ is greater than that of the $\mathrm{Al}$ element. As the fiber diameter increases, the volume fraction of the 304 stainless steel wire inside the composite increases, which causes an increase of the $\mathrm{Fe}$ content. When the diameter of the metal fiber is small, the microporosity between the metal fiber and matrix is relatively small, so the $\mathrm{Al}$ element plays a dominant role in the local area. When the metal fiber diameter is large, the microporosity between the metal fiber and matrix is relatively large, so the Fe plays a leading role in the local area. Therefore, as the diameter of the metal fiber increases, the resistivity increases first and then decreases.

\section{CONCLUSIONS}

1) $\mathrm{CC}-\mathrm{M}_{\mathrm{f}} / \mathrm{Al}$ composites rarely had microporosity between the copper-coated metal fiber and the matrix, and the eutectic silicon is uniformly distributed in the $\alpha$ solid-solution body. However, the $\mathrm{CU}-\mathrm{M}_{\mathrm{f}} / \mathrm{Al}$ composites had microporosity between the copper-uncoated metal fiber and the matrix, and the eutectic silicon is densely distributed in the vicinity of the fiber, which causes stress concentration near the fiber during the tension test, and a decrease of the mechanical properties. Overall, copper-coated on the surface of the metal fiber can greatly improve the interfacial bonding strength between the metal fiber and the $\mathrm{Al}-\mathrm{Si}-\mathrm{Cu}$ matrix. 
2) The mechanical properties of the $\mathrm{CC}-\mathrm{M}_{\mathrm{f}} / \mathrm{Al}$ composites are much better than that of the $\mathrm{CU}-\mathrm{M}_{\mathrm{f}} / \mathrm{Al}$ composites. When the diameter of the fiber increases, the mechanical properties of the composite material first increase and then decrease. When the diameter of the copper-coated fiber is $0.1 \mathrm{~mm}$, i.e., the volume fraction of the metal fiber is $0.17 \%$, the tensile strength of the CC- $\mathrm{M}_{\mathrm{f}} / \mathrm{Al}$ composites reaches a maximum of 341.04 $\mathrm{MPa}$, and the microhardness of the $\mathrm{CC}-\mathrm{M}_{\mathrm{f}} / \mathrm{Al}$ composites reaches a maximum value of $129.1 \mathrm{HV}$. The elongation of the $\mathrm{CC}-\mathrm{M}_{\mathrm{f}} / \mathrm{Al}$ composites reaches a maximum of $54.24 \mathrm{~mm}$.

3) The resistivity of the $\mathrm{CC}-\mathrm{M}_{\mathrm{f}} / \mathrm{Al}$ composite is much smaller than that of the $\mathrm{CU}-\mathrm{M}_{\mathrm{f}} / \mathrm{Al}$ composites, and the resistivity of the $\mathrm{Al}-\mathrm{Si}-\mathrm{Cu}$ matrix composites increases first and then decreases with an increase of the diameter of the metal fiber. When the diameter of the copper-uncoated fiber is $0.2 \mathrm{~mm}$, the resistivity reaches a maximum of $27.1 \mathrm{u} \Omega \cdot \mathrm{mm}$.

\section{Acknowledgements}

This project is funded by National Key Research and Development Program of China (Grant No. 2018YFB1307900), Key Research Program of Shanghai Science and Technology Commission (Grant No. 16030501200), National Natural Science Foundation of China (Grant No. 51805314) and Shanghai University of Engineering and Science (Grant No. E3-050118-01002). The Robot Functional Materials Preparation Laboratory in Shanghai University of Engineering Science is also gratefully acknowledged.

\section{REFERENCES}

${ }^{1}$ A. K. Prasada Rao, B. S. Murty, M. Chakraborty, Improvement in tensile strength and load bearing capacity during dry wear of Al-7Si alloy by combined grain refinement and modification, Materials Science \& Engineering A, 395 (2005), 323-326, doi:10.1016/j.msea. 2004.12.053

${ }^{2}$ H. Wan, N. C. Si, G. L. Liu, C. Wei, B. Zheng, Y. S. Li, Influence of Strontium Addition on Microstructure and Mechanical Properties of an $\mathrm{Al}-10 \mathrm{Si}-5 \mathrm{Cu}$ Alloy, Transactions of the Indian Institute of Metals, 70 (2017), 2039-2046, doi:10.1007/s12666-016-1025-2

${ }^{3}$ H. U. Zhi, H. Yan, Y. S. Rao, Effects of samarium addition on microstructure and mechanical properties of as-cast Al-Si-Cu alloy, Transactions of Nonferrous Metals Society of China, 23 (2013), 3228-3234, doi:10.1016/S1003-6326(13)62857-5

${ }^{4}$ K. S. Alhawari, M. Z. Omar, M. J. Ghazali, M. S. Salleh, M. N. Mohammed, Microstructural evolution during semisolid processing of $\mathrm{Al}-\mathrm{Si}-\mathrm{Cu}$ alloy with different $\mathrm{Mg}$ contents, Transactions of Nonferrous Metals Society of China, 27 (2017), 1483-1497, doi:10.1016/S1003-6326(17)60169-9

${ }^{5}$ B. L. Dasari, M. Morshed, J. M. Nouri, D. Brabazon, S. Naher, Mechanical properties of graphene oxide reinforced aluminium matrix composites, Composites Part B: Engineering, 145 (2018), 136-144, doi:10.1016/j.compositesb.2018.03.022
${ }^{6}$ K. Hamada, M. Taya, K. Inoue, J. H. Lee, K. Mizuuchi, Thermomechanical behavior of TiNi shape memory alloy fiber reinforced 6061 aluminum matrix composite, Metallurgical \& Materials Transactions A, 29 (1998), 1127-1135, doi:10.1007/s11661-9981022-0

${ }^{7}$ M. J. Crimp, A novel approach to intermetallic matrix composite (IMC) processing, Materials Science Engineering A, 192 (1995), 633-639, doi:10.1016/0921-5093(94)03303-X

${ }^{8}$ H. A. Alhashmy, M. Nganbe, Laminate squeeze casting of carbon fiber reinforced aluminum matrix composites, Materials \& Design, 67 (2015), 154-158, doi:10.1016/j.matdes.2014.11.034

${ }^{9}$ H. Suzuki, H. Sekine, Fracture Energy and Fracture Behavior of Short-Fiber-Reinforced SMC Composites, Key Engineering Materials, 430 (2010), 31-40, doi:10.4028/www.scientific.net/KEM. 430.31

${ }^{10}$ T. Wang, Y. X. Zhao, S. H. Fu, Y. Zhang, W. H. Zeng, J. H. Wei, Z. Li, Progress and Key Problems in Research and Fabrication of Fiber Reinforced Metal Matrix Composite, Journal of Aeronautical Materials, 33 (2013), 87-96, doi:info:doi/10.3969/j.issn.10055053.2013.2.015

${ }^{11}$ Y. F. Lei, Y. D. Song, D. P. Gao, Analysis of Elastoplastic Behavior of Fiber Reinforced Metal Matrix Composites, Mechanical Science and Technology, 22 (2003), 982-985, doi:10.13433/j.cnki.10038728. 2003. 06. 038

${ }^{12}$ X. B. Mang, Preparation and mechanical property of long carbon fibre reinforced aluminum matrix composite, Light Alloy Fabrication Technology, 43 (2015), 64-67, doi:10.13979/j.1007-7235.2015. 07.015

${ }^{13}$ S. N. Yang, S. Y. Yang, Research on Mechanical Properties of TiNi Shape Memory Alloy Wires Reinforced Al Matrix Composite Material, Advanced Materials Research, 1120-1121 (2015), 502-506, doi:10.4028/www.scientific.net/AMR.1120-1121.502

${ }^{14}$ T. T. Pan, T. He, Y. M. Huo, X. J. Shi, S. S. Chen, K. P. Yu, A. N. Sun, Effect of the Processing Parameters on the Microstructure and Properties of the ZL116 Aluminium Alloy After Vacuum Suction Casting, Mater. Tehnol., 52 (2018) 795-801, doi:10.17222/mit. 2018.094

${ }^{15}$ Z. Szklarz, H. Krawiec, L. Rogal, The effect of vacuum suction casting on the microstructure and corrosion behavior of aluminium alloy 2017, Materials Science \& Engineering B, 240 (2019), 23-32, doi:10.1016/j.mseb.2019.01.006

${ }^{16}$ L. H. Qi, Y. Q. Ma, J. M. Zhou, X. H. Hou, H. J. Li, Effect of fiber orientation on mechanical properties of 2D-Cf /Al composites by liquid-solid extrusion following Vacuum infiltration technique, Materials Science and Engineering: A, 625 (2015), 343-349, doi:10.1016/j.msea.2014.12.025

${ }^{17}$ J. J. Zhang, S. C. Liu, Y. X. Zhang, Y. Dong, Y. P. Lu, T. J. Li, Fabrication of woven carbon fibers reinforced $\mathrm{Al}-\mathrm{Mg}$ (95-5 wt\%) matrix composites by an electromagnetic casting process, Journal of Materials Processing Technology, 226 (2015), 78-84, doi:10.1016/j.jmatprotec.2015.06.040

${ }^{18}$ B. Bhav Singh, M. Balasubramanian, Processing and properties of copper-coated carbon fibre reinforced aluminium alloy composites, Journal of Materials Processing Technology, 209 (2009), 2104-2110, doi:10.1016/j.jmatprotec.2008.05.002

${ }^{19}$ N. Kheradmand, A. Barnoush, H. Vehoff, Investigation of the role of grain boundary on the mechanical properties of metals, Iournal of Physics, 240 (2010), 012-017, doi:10.1088/1742-6596/240/1/012017

${ }^{20}$ R. A. Sanguinetti Ferreira, C. Arvieu, J. M. Quenisset, Effects of pressure and thermal exposure on the $\mathrm{Ti} / \mathrm{SiC} / \mathrm{C}$ composites produced by continuous binder-powder coating, Scripta Materialia, 53 (2006), 329-333, doi:10.1016/j.scriptamat.2005.04.007 